\title{
Performance assessment of imported ELISA in the serodiagnosis of the enzootic bovine leukosis in herds of Pernambuco state, Brazil*
}

\author{
Avaliação do desempenho de ELISA importado no sorodiagnóstico \\ da leucose enzoótica bovina em rebanhos do estado de Pernambuco, Brasil
}

\author{
Luiz Carlos Fontes Baptista Filho ${ }^{1 * *}$ (D), Artur Cesar de Carvalho Fernandes ${ }^{2}$ (D), \\ Tamyres Izarelly Barbosa da Silva ${ }^{3}$ (D), Taciana Rabelo Ramalho Ramos ${ }^{1}$ (D), \\ Lúcio Esmeraldo Honório de Melo ${ }^{4}$
}

\begin{abstract}
Enzootic bovine leukosis (EBL) is an infectious disease of cosmopolitan distribution and chronic character caused by a virus of the Retroviridae family, bovine leukemia virus (BLV). The epidemiological situation of EBL in Brazil has motivated studies to improve its diagnosis, based on the recommended serological techniques: agar gel immunodiffusion (AGID) and enzyme-linked immunosorbent assay (ELISA). This study was designed to evaluate the use of imported ELISA for the detection of BLV in dairy herds raised in Pernambuco, Brazil, comparing it to AGID. Blood serum samples from 327 dairy cattle from the state of Pernambuco were tested to AGID and the imported commercial ELISA CHEKIT-Leucose-serum, produced by the IDEXX ${ }^{\circledR}$ laboratory for the diagnosis of EBL. Discarding 25 inconclusive samples from one or both tests, 302 samples were analyzed, being $24.1 \%$ positive $(73 / 302)$ in the AGID and 45\% (136/302) in the ELISA, which compared to the AGID, a technique considered standard, presented sensitivity of $98.6 \%$, specificity of $72 \%$ and Kappa coefficient of 0.55 . The lack of agreement in the diagnostic methods was probably due to the high sensitivity of the ELISA, which makes it possible to detect antibodies even in situations with low serum levels. Although AGID has been shown to be an efficient test so far, in more advanced stages of an EBL control and eradication program, with low prevalence rates, ELISA will present better performance, due to its higher sensitivity, avoiding the permanence of animals that spread the disease in the herds.
\end{abstract}

KEYWORDS: cattle; bovine leukemia virus; AGID; serology.
RESUMO: A leucose enzoótica bovina (LEB) é uma doença infecciosa de distribuição cosmopolita e caráter crônico causada por um vírus da família Retroviridae, o vírus da leucemia bovina (VLB). A situação epidemiológica da LEB no Brasil vem motivando estudos para o aprimoramento do seu diagnóstico, tendo como base as técnicas sorológicas recomendadas: imunodifusão em gel de ágar (IDGA) e EnzymeLinked Immunoabsorbent Assay (ELISA). Este estudo teve como objetivo avaliar o uso de ELISA importado para a detecçáo do VLB em rebanhos leiteiros criados em Pernambuco, Brasil, comparando-o ao IDGA. Amostras de soro sanguíneo de 327 bovinos leiteiros do estado de Pernambuco foram testadas para IDGA e ELISA comercial importado CHEKIT-Leucose-serum, produzido pelo laboratório IDEXX ${ }^{\circledR}$ para o diagnóstico da LEB. Descartadas 25 amostras inconclusivas de um ou ambos os testes, foram analisadas 302 amostras, sendo 24,1\% positivas (73/302) na IDGA e $45 \%$ (136/302) no ELISA, que em relação à IDGA, técnica considerada padrão, apresentou sensibilidade de $98,6 \%$, especificidade de $72 \%$ e coeficiente Kappa de 0.55. A falta de concordância entre os métodos diagnósticos deveu-se, provavelmente, à elevada sensibilidade do ELISA, que possibilita detectar anticorpos mesmo em situações com baixos teores séricos. Apesar da IDGA se mostrar até o momento um teste eficiente, emetapas mais avançadas de um programa de controle e erradicaçáo da LEB, com baixos índices de prevalência, o ELISA apresentará melhor desempenho, por possuir maior sensibilidade, evitando-se a permanência de animais disseminadores da doença nos rebanhos.

PALAVRAS-CHAVE: bovinos; vírus da leucemia bovina; IDGA; sorologia.

\footnotetext{
'Universidade Federal Rural de Pernambuco - Garanhuns (PE), Brazil

¿Universidade Federal da Paraíba - Areia (PB), Brazil

${ }^{3}$ Universidade Federal do Acre - Rio Branco (AC), Brazil

${ }^{4}$ Universidade Federal Rural de Pernambuco - Recife (PE), Brazil

* This paper is part of the doctoral thesis of the first author.

**Corresponding author: luizmedvet@hotmail.com

Received on: 05/22/2018. Accepted on: 08/29/2019
} 
Enzootic bovine leukosis (EBL) is an infectious-contagious, cosmopolitan, transmissible disease caused by the bovine leukemia virus (BLV), an exogenous lymphotropic Deltaretrovirus $\mathrm{B}$, which primarily compromises the infected bovine lymphoid system, especially lymph nodes, which can be progressively replaced by neoplastic tissue, which may or may not cause leukemization (OIE, 2012; FRIE; COUSSENS, 2015).

It is known from previous studies that EBL acts as a risk factor for the occurrence of opportunistic diseases, especially tuberculosis (FERNANDES et al., 2011; MENDES et al., 2011; FRIE; COUSSENS, 2015) and mastitis in catthe (DELLA LIBERA et al., 2015), demanding even greater attention from researchers and health authorities.

EBL is associated with large economic losses and studies about its prevalence show its wide distribution in Brazilian dairy herds, especially in Pernambuco, with an alarming prevalence of $24 \%$, considered the largest in the Northeast region, what characterizes the enzootic state in which the local herds are (FERNANDES et al., 2011).

The epidemiological situation of EBL in Brazil has motivated studies to improve its diagnosis, based on the serological techniques recommended by the World Organization for Animal Health (OIE): agar gel immunodiffusion (AGID) and enzyme-linked immunosorbent assay (ELISA) (EL-HAFEIZ et al., 2010; DIAS et al., 2012; TIRZIU et al., 2014; MARESCA et al., 2015; KUCZEWSKI et al., 2018).

The ELISA has some advantages compared to AGID in the diagnosis of EBL, such as the result in a shorter time after performing the test and the possibility of evaluating serological pools in herd monitoring. In addition, it stands out for its high sensitivity allowing the identification of animals with low serum antibody titration (BRENNER et al., 1994; TRONO et al., 2001; EL-HAFEIZ et al., 2010; THRUSFIELD, 2013; TIRZIU et al., 2014; KUCZEWSKI et al., 2018). These benefits are leading some countries to replace AGID with ELISA in their eradication programs (MAMMERICKX et al., 1985; GIBSON, 1995; MARESCA et al., 2015).

Given the relevance of EBL in Brazil, the objective of this study was to evaluate the use of ELISA (CHEKIT-Leucoseserum - IDEXX $\left.{ }^{\oplus}\right)$ for the detection of BLV in dairy herds raised in Pernambuco, comparing it to AGID (TECPAR ${ }^{\circledR}$ ).

Were used in the study a total of 327 productive dairy cattle from 12 herds located in cities of the metropolitan region of Recife, Zona da Mata, Agreste and Sertáo of Pernambuco, chosen for convenience.

For the serodiagnosis of EBL, blood samples were collected by jugular venipuncture, with a vacuum collection system, in tubes with a capacity of $10 \mathrm{~mL}$. The collected blood was kept at room temperature until blood clot retraction, then transported to the laboratory under refrigeration, where they were centrifuged for 10 minutes at $1,000 \mathrm{~g}$. The obtained serum was transferred to polypropylene tubes and stored in a freezer at $-20^{\circ} \mathrm{C}$.
The Enzyme-Linked Immunosorbent assay was performed using the imported commercial ELISA CHEKIT-Leucose-serum kit produced by the IDEXX ${ }^{\circledast}$ laboratory, following the manufacturers recommendations. Microplate readings were performed on a Thermo ${ }^{\circledR}$ Multiskan reader, fitted with a $450 \mathrm{~nm}$ filter.

To perform the Agar Gel Immunodiffusion, the Ouchterlony Double Radial Immunodiffusion technique was used, using antigen (gp51) produced by the Instituto de Tecnologia do Paraná $\left(\mathrm{TECPAR}^{\circledR}\right)$, according to the methodology previously recommended and published (MILLER; VAN DER MAATEN, 1977).

In order to homogenize the sample groups, inconclusive samples to one or both tests were disregarded. Results were statistically evaluated for sensitivity and specificity of ELISA and the agreement between the two tests were measured (Kappa coefficient), considering AGID as the standard technique (THRUSFIELD, 2013).

The experiment was previously approved by the Animal Ethics Committee of the Universidade Federal Rural de Pernambuco, under license number 010/2013.

The sampling was defined as 302 samples, considering that 25 were disregarded for presenting inconclusive results, 6 to ELISA and 19 to AGID.

Regarding the ELISA, 45\% showed positive results (136/302), while in the AGID 24.1\% (73/302). Of the 73 samples considered positive for AGID, only $1(1.36 \%)$ was not detected by ELISA (Table 1).

Thus, with ELISA it was possible to identify as seroreactive 64 samples that had not been identified in the AGID. This is probably due to the high sensitivity of the ELISA test, which makes it possible to identify antibodies even in situations with low serum levels (BRENNER et al., 1994; TRONO et al., 2001; EL-HAFEIZ et al., 2010; THRUSFIELD, 2013; TIRZIU et al., 2014; KUCZEWSKI et al., 2018).

False negative reactions in AGID associated with low serum antibody levels may be commonly observed in situations such as incipient infections when seroconversion has not yet occurred, and in the pre and postpartum period when immunoglobulin is recruited for colostrum production, decreasing their serum level. In this context, the incidence of false negative animals is a warning of the need for further studies on the

Table 1. Association of results from agar gel immunodiffusion and enzyme-linked immunosorbent assay in the diagnosis of bovine enzootic leukosis in naturally infected dairy cattle from herds of Pernambuco state, Brazil.

\begin{tabular}{|c|c|c|c|c|}
\hline & \multicolumn{4}{|c|}{ AGID } \\
\hline \multirow{4}{*}{ ELISA } & & Positive & Negative & Total \\
\hline & Positive & 72 & 64 & 136 \\
\hline & Negative & 1 & 165 & 166 \\
\hline & Total & 73 & 229 & 302 \\
\hline
\end{tabular}

AGID: agar gel immunodiffusion; ELISA: enzyme-linked immunosorbent assay; Kappa coefficient $=0.55$ 
confirmation of these results, and their impact on the control of EBL in dairy herds, especially regarding the consequence of the maintenance of these animals in a herd (FLORES et al., 1989; DELLA LIBERA et al., 2015; TSUTSUI et al., 2016).

When analyzing the ELISA results compared to the AGID, technique already consolidated and considered standard, it was found a sensitivity of $98.6 \%$ and a specificity of $72 \%$. The Kappa coefficient found was 0.55 , and the agreement was considered "substantial" (THRUSFIELD, 2013).

The specificity of the ELISA kit underscores the need for adjustments in order to elevate it, and for in vitro studies that allow the monitoring of animals known to be positive and negative, to elucidate questions about false negative and positive results.

The agreement in tests was considered highly probable due to the higher ELISA detection capacity (BRENNER et al., 1994; TRONO et al., 2001; EL-HAFEIZ et al., 2010; THRUSFIELD, 2013; TIRZIU et al., 2014; KUCZEWSKI et al., 2018), generating disagreement between the tests.

The result also demonstrates the importance of using both tests (ELISA and AGID) in different epidemiological situations of EBL; considering that in a phase of high prevalence
AGID, due to its high specificity (MILLER; VAN DER MAATEN, 1977; KUCZEWSKI et al., 2018), will have better efficiency, and that later ELISA would be applied, inserted in a situation with greater control and lower prevalence, due to its high sensitivity.

JULIARENA et al. (2007) demonstrated that high proviral load is directly related to the transmissibility of the disease. This is further indicative that AGID, in the early stages of a control program, is a sufficient tool, given that low proviral load is of less importance in the epidemiological chain of the disease.

The CHEKIT-Leukose-serum ELISA kit (IDEXX ${ }^{\circledR}$ ) results demonstrate satisfactory sensitivity, specificity and agreement values, especially regarding sensitivity, but there is a need for comparative studies with higher specificity tests, in order to clarify possible cases of false positives and negatives.

Although AGID has been shown to be an efficient test so far, in more advanced stages of an EBL control and eradication program, with low prevalence rates, ELISA will present better performance, due to its greater sensitivity, avoiding the permanence of animals that spread the disease in the herds.

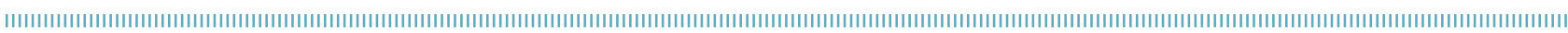
REFERENCES

BRENNER, J.; MOSS, S.; MOALEM, U. A comparative study of the Elisa and AGID techniques for the detection of bovine leucosis virus antibodies in bovine serum and milk. Israel Journal of Veterinary Medicine, v.49, p.165-67, 1994.

DELLA LIBERA, A.M.M.P.; DE SOUZA, F.N.; BATISTA, C.F.; SANTOS, B.P.; DE AZEVEDO, L.F.F.; SANCHEZ, E.M.R.; BLAGITZ, M.G. Effects of bovine leukemia virus infection on milk neutrophil function and the milk lymphocyte profile. Veterinary Research, v.46, n.1, p.2, 2015. https://doi.org/10.1186/s13567-014-0125-4

DIAS, N.L.; FONSECA JÚNIOR, A.; RODRIGUES, D.S.; CAMARGOS, A.F. PCR em tempo real para diagnóstico da leucose enzoótica bovina. Ciência Rural, v.42, n.8, p.1434-1439, 2012. http:// dx.doi.org/10.1590/SO103-84782012005000053

EL-HAFEIZ, Y.G.M.; METIAS, K.N.; IBRAHIM, I.G.A. Comparative serological detection of enzootic bovine leukosis virus (EBLV) in cattle sera. Global Veterinaria, v.4, n.3, p.267-270, 2010.

FERNANDES, A.C.C.; TENÓRIO, T.G.S.; SILVA, T.I.B.; MENDES, E.I.; BAPTISTA FILHO, L.C.F.; MELO, L.E.H. Leucose enzoótica e tuberculose dos bovinos: estudo retrospectivo e prospectivo da ocorrência em rebanhos leiteiros do estado de Pernambuco. Veterinária e Zootecnia, v. 18, n.4, p.728-732, 2011.

FLORES, E.F.; WEIBLEN, R.; PEREIRA, N.M.; PORTOLANN, J.A.B.; SANCHEZ, C.M.; SOARES, M.R.L. Utilização da imunodifusão em gel ágar (IDGA) no controle da infecção pelo vírus da leucose bovina (VLB). Ciência Rural, v.19, n.1-2, p.169-176, 1989.
FRIE, M.C.; COUSSENS, P.M. Bovine leukemia virus: A major silent threat to proper immune responses in cattle. Veterinary Immunology and Immunopathology, v.163, n.3-4, p.103-114, 2015. https://doi.org/10.1016/j.vetimm.2014.11.014

GIBSON, L.A. Testing for enzootic bovine leukosis. Veterinary Record, v.136, n.6, p.156, 1995. https://doi.org/10.1136/vr.136.6.156

JULIARENA, M.A.; GUTIERREZ, S.E.; CERIANI, C. Determination of proviral load in bovine leukemia virus-infected cattle with and without lymphocytosis. American Journal of Veterinary Research, v.68, n. 11 , p.1220-1225, 2007. https://doi.org/10.2460/ajvr.68.11.1220

KUCZEWSKI, A.; ORSEL, K.; BARKEMA, H.W.; KELTON, D.F.; HUTCHINS, W.A.; VAN DER MEER, F.J. Short communication: Evaluation of 5 different ELISA for the detection of bovine leukemia virus antibodies. Journal of Dairy Science, v.101, n.3, p.24332437, 2018. https://doi.org/10.3168/jds.2017-13626

MAMMERICKX, M.; PORTETELLE, D.; BURNY, A. Application of an enzyme-linked immunosorbent assay (ELISA) involving monoclonal antibody for detection of BLV antibodies in individual or pooled bovine milk samples. Zentralblatt Fur Veterinarmedizin Reihe B, v.32, n.7, p.526-533, 1985. https:// doi.org/10.1111/j.1439-0450.1985.tb01990.x

MARESCA, C.; COSTARELLI, S.; DETTORI, A.; FELICI, A.; ISCARO, C.; FELIZIANI, F. Enzootic bovine leukosis: Report of eradication and surveillance measures in Italy over an 8-year period (20052012). Preventive Veterinary Medicine, v. 1 19, n.3-4, p.222-226, 2015. https://doi.org/10.1016/j.prevetmed.2015.02.024 
MENDES, E.I.; MELO, L.E.H.; TENÓRIO, T.G.S.; SÁ, L.M.; SOUTO, R.J.C.; FERNANDES, A.C.C.; SANDES, H.M.M.; SILVA, T.I.B. Intercorrência entre leucose enzoótica e tuberculose em bovinos leiteiros do estado de Pernambuco. Arquivos do Instituto Biológico, v.78, n. 1, p.1-8, 2011.

MILLER, J.M.; VAN DER MAATEN, M.J. Use of glycoprotein antigen in the immunodiffusion test for bovine leukemia virus antibodies. European Journal of Cancer (1965), v.13, n.12, p.1369-1371,1373-1375, 1977. https://doi. org/10.1016/0014-2964(77)90149-9

OFFICE INTERNATIONAL DES ÉPIZOOTIES. Código Zoosanitário Internacional. 2012. Available from: <https:// www.oie.int/fileadmin/Home/eng/Health_standards/

tahm/2.04.10_EBL.pdf>. Access on: Apr. 152018. THRUSFIELD, M. Veterinary epidemiology. 3. ed. Amsterdam: Elsevier, 2013.
TIRZIU, E.; CUMPĂNĂȘOIU, C.; NICHITA, I.; REMAN, G.D.; SONEA, C.; ȘEREȘ, M. Performance assessment of three tests applied in enzootic bovine leukosis diagnosis. Romanian Biotechnological Letters, v.19, n.5, p.9666-9677, 2014.

TRONO, K.G.; PÉREZ-FILGUEIRA, D.M.; DUFFY, S.; BORCA, M.V.; CARRILLO, C. Seroprevalence of bovine leukemia virus in dairy cattle in Argentina: comparison of sensitivity and specificity of different detection methods. Veterinary Microbiology, v.83, n.3, p.235-248, 2001 . https://doi.org/10.1016/ s0378-1135(01)00420-5

TSUTSUI, T.; KOBAYASHI, S.; HAYAMA, Y.; YAMAMOTO, T. Fraction of bovine leukemia virus-infected dairy cattle developing enzootic bovine leukosis. Preventive Veterinary Medicine, v.124, p.96-101, 2016. https://doi.org/10.1016/j. prevetmed.2015.11.019 